Golden Gate University School of Law GGU Law Digital Commons

$11-7-2011$

\title{
The Priority Fight Between the Second Mortgagee and the Subrogated Insurance Carrier
}

Roger Bernhardt

Golden Gate University School of Law, rbernhardt@ggu.edu

Follow this and additional works at: http://digitalcommons.law.ggu.edu/pubs

Part of the Property Law and Real Estate Commons

\section{Recommended Citation}

Bernhardt, Roger, "The Priority Fight Between the Second Mortgagee and the Subrogated Insurance Carrier" (2011). Publications. Paper 465.

http://digitalcommons.law.ggu.edu/pubs/465

This Article is brought to you for free and open access by the Faculty Scholarship at GGU Law Digital Commons. It has been accepted for inclusion in Publications by an authorized administrator of GGU Law Digital Commons. For more information, please contact jfischer@ggu.edu. 


\title{
The Priority Fight Between the Second Mortgagee and the Subrogated Insurance Carrier
}

\section{Roger Bernhardt}

\author{
Take This Quiz First
}

The mortgagor torches the property; the carrier pays the first mortgage and takes an assignment of that lien. Who is then entitled to the remaining value of the property: the carrier as assignee of the first mortgagee - or the second mortgagee - who was a named insured under the policy but whose loss fell outside of its policy limits? That is the intriguing issue raised by an Alabama Supreme Court decision in January of this year. Think how you would decide the matter before reading on.

\section{The Complete Story}

The actual facts in Certain Underwriters at Lloyds v Kirkland, 2011 WL 49851 (Jan 7, 2011), were rather more complicated than this oversimple teaser, so here is a more accurate description of all that happened. Lunceford purchased a restaurant from the Kirklands for $\$ 1,850,000$, exchanging some other property and giving Kirklands a note for $\$ 550,000$, secured by a second mortgage on the real property, and further secured by a first lien on the personal property on the premises. Lunceford got the rest of the financing through an acquisition loan from Vision Bank for $\$ 1,110,000$, which was secured by a first mortgage on the real property, and a second on the personalty. Underwriters issued its insurance policy with $\$ 1,500,000$ coverage for the real property and \$250,000 for the personal property, the policy including endorsements insuring both Vision and Kirklands as well as Lunceford.

Two years later, Lunceford set fire to the restaurant; Underwriters paid Vision \$1,072,000 (the cash value of the real property); and also paid Kirklands $\$ 250,000$ for the personal property. Those insurance payments, however, left Vision short \$80,000 on its first mortgage, and Kirklands short \$370,000 on their second mortgage.

The land apparently had some significant residual value, because both Underwriters and Kirklands began maneuvering to get it. Underwriters obtained a pro tanto assignment of Vision's mortgage for the \$1,072,000 it had given Vision; Kirklands then paid Vision the unpaid balance of its first mortgage - $\$ 80,000$ - and took their own partial assignment from Vision for that amount.

Underwriters and Kirkland then disagreed as to who could next reach whatever was left.

\section{Ranking the Losses}

To recap, the parties were left with four losses (not listed in ranking order) : Underwriters - a) $\$ 1,072,000$ (paid to Vision) and b) $\$ 250,000$ (paid to Kirklands); Kirklands - c) $\$ 80,000$ (paid to Vision) and d) \$370,000 (unpaid on its second).

Two of those four items are easy to rank. Kirklands’ $\$ 80,000$ claim for the payment they made to Vision (c) must be first, because it came from an assignment of Vision's senior rights in the first mortgage for that amount. Conversely, Underwriters $\$ 250,000$ loss (b) must come in last, because it was based on a payment to Kirklands, and Underwriter's policy had declared that 
Kirkwoods rights "to recover the full amount of the mortgageholder's claims will not be impaired” by Underwriters rights. (The nonimpairment clause.)

The difficult issue was ranking Underwriters (a) claim of \$1,072,000, against Kirklands' (d) claim of \$370,000. An Alabama trial court thought that Kirklands' claim was superior, but the state's Supreme Court ruled the other way: Underwriters was held to be prior because it had a partial assignment from Vision of that much of its first mortgage, which mortgage had priority over any claim by Kirklands arising under their second mortgage; since Vision was in front of Kirklands for that \$1,072,000 (because its mortgage was a first mortgage), then Vision's assignee, Underwriters, stood in those same shoes and in the same place in line.

\section{Alabama and Massachusetts Stand Together}

The reasoning of the Alabama Supreme Court duplicated that of the Massachusetts Supreme Court in a similar case, decided a decade earlier: The Money Store v Hingham Mutual Fire Insurance, 718 NE2d 840, 1999. Both high courts rejected contentions that the carrier's position as assignee of the first mortgagee should be subordinated to the second mortgagee on the ground that the nonimpairment clauses included in those policies applied to both lenders. Both held that a nonimpairment clause would disable a carrier from seeking priority for repayment of what it had paid to its insured as against that same insured's remaining claim for the unpaid balance of its insured's loss - a proposition that is also true for carrier's subrogation rights in general - but that a nonimpairment clause does not estop the carrier from asserting the priority of its claim of subrogation to an insured senior it has paid over a different junior lender, even if insured under the same policy and with the same nonimpairment clause protecting it.

“The Kirklands' interest was always subordinate to the interest of the first mortgagee. Therefore, the Kirklands stand in the same position they were in before Vision Bank assigned its interest to Underwriters. Thus, we cannot say that recognizing the priority of Underwriters interest in the first mortgage over the Kirklands' interest in the second mortgage impairs the Kirklands' right to recover its mortgage debt.”

Kirklands had attempted to get around this logic by arguing that subrogation theory never allows an insurer to trump its own loss payee, but the Alabama Court - quoting the Massachusetts Court - observed that Underwriters claim was not based on subrogation but rather on assignment, different doctrines which "are not the functional equivalent of each other. The former speaks of broader equitable rights and remedies. Assignment is legal in nature and has an established meaning ... with respect to the rights of an assignee of a first mortgage.” Thus what might be true for subrogation was not true for assignment.

\section{Some Consolation}

So did you, reader, guess wrong about who had priority? Did you conclude that, in the opening example of this article, the second mortgagee's claim should rank above its carrier's? If you did make that mistake, you may nevertheless take some comfort from the fact that the Alabama trial court also got it wrong, as did the trial and appeal courts in Massachusetts ten years earlier. Indeed, the Massachusetts Appeals Court had been even more wrongheaded because it had opined that there was no real distinction between assignment and subrogation; to it, "the assignment clause is the functional equivalent of subrogation.” 
More seriously, the Massachusetts Appeals Court had believed that public policy ran in favor of the junior lender:

"Neither the subrogation mechanism nor the assignment device is supposed to bestow a windfall on the insuror as to junior mortgagees. Were that not so, the obligation to pay junior mortgagees would be meaningless; insurers could and would cheerfully pay off the first mortgagee, foreclose and shut out the junior mortgagees.”

Ironically, the Massachusetts Appeals Court, in committing this error, relied on what it thought was a generally accepted principle:

"A New Jersey court, deciding that an insurer's rights from subrogation and assignment may only be exercised after the mortgagee has recovered its debt from a combination of insurance policy proceeds, foreclosure proceeds, and payments by the mortgagor, thought the relative paucity of cases expressly so holding was "probably because that is so obvious and well settled under our form of mortgage clause [the standard clause] that the question is seldom raised.” First Fed. Sav. \& Loan Assn. of Hammonton v. Hartford Fire Ins. Co., 100 N.J.Super. 252, 254, 241 A.2d 653 (1968).

Indeed, the Maryland Court of Appeals [its high court] had come to a similar conclusion (Mutual Fire Ins v Dilworth, 173 Atl 22, 1934), basinb its result mainly on the fact that the policy before it (as did the policy in Kirkland) included not only a nonimpairment clause, but also the standard provision that the mortgagee's protection "shall not be invalidated by any act or neglect of the mortgagor”. (A “no neglect” clause.) Because of the inclusion of that clause:

"if the claim for preference of lien made by the insurance company as to the first mortgage is well founded, it must be because of an act of the mortgagor-owner which invalidated the policy as to him, and which permitted the insurance company to validly claim nonliability as to the mortgagor and owner. By the terms of the clause under consideration, the insurance company only becomes entitled to be subrogated and to have an assignment of the first mortgage, upon its payment, if and when the owner is guilty of some act or neglect which entitles the insurance company to claim nonliability as to him. It follows that this act or neglect is the basis for the insurance company's claim to a preference over the [second mortgagees], the allowance of which would be in the teeth of the provision of the clause which provides that no act or neglect of the mortgagor or owner shall invalidate the interest of the appellees; they being mortgagees .... The second mortgagees were as certainly protected under the terms of the policy as the first mortgagee; and the policy issued by the insurance company afforded that protection.***

The logical, true, and equitable construction of the terms of this contract is that the insurance company, upon the payment to the first mortgagee, is subrogated to the rights of the first mortgagee, as against the mortgagor or owner, but not as against the second mortgagees. Any other construction, in our opinion, would not be equitable, resulting as it would in no loss whatever to the insurance company, and impairment, if not a total destruction, of the value of the second mortgage, which, as heretofore several times stated, the insurance company contracted should not be invalidated or impaired by any act of the mortgagor or owner, or any subrogation or assignment by the first mortgagee to it. (italics mine) 
A New York decision, Perretta v. St. Paul Fire \& Marine Ins. Co., 106 Misc. at 99-101, 174 N.Y.S. at 136-137, also appears to hold pretty much the same. More importantly, even so eminent an authority as Nelson and Whitman come to the same conclusion:

But when the second mortgagee also is included in the mortgage clause in the policy, the insurer's rights by subrogation are postponed to the second mortgagee's rights. This is right because if the insurer were permitted, through subrogation, to enforce the first mortgage against the property left after the destruction, it would result in making the property satisfy the first mortgage twice-once by the destruction of enough of it to justify the insurer in paying off the first mortgage, and again by enforcement of the assigned first mortgage on the property left-before the second mortgagee could enforce its claim. This would impair the second mortgagee's ability to collect its claim and thus violate the provision in a standard mortgage clause that the insurer's subrogation shall not impair the right of the mortgagee to recover the full amount of the claim. Nelson \& Whitman, Real Estate Finance Law, Sec. 4.14

(Although Nelson and Whitman do add a qualifying footnote. "However, if the insurer proceeds to pay the first mortgage in full and take an assignment of it, and then to foreclose it, the authorities are divided as to whether the insurer may destroy the second mortgage by doing so", citing all of the cases I have described.)

So perhaps readers who came out on the other side did not reason wrongly, but simply chose the minority rather than the majority rule (although it may be stretching matters to call a division between two jurisdictions on one side and three on the other a majority/minority split when there are forty five others yet to be heard from.)

\section{Why the Split?}

Priorities questions often lead to divided results when technically correct conclusions lead to results that are perceived as inequitable. Technically, a carrier, or anyone taking by assignment (or subrogation) from a party who stands in first position, should continue to stand in front of one who was in second position; but it also seems inequitable to allow that proposition to thereby deny to a second lender the very insurance protection that it had sought to obtain by having itself named as a loss payable lender with a nonimpairment endorsement. That is the same quandary that bedevils our courts in attempting to rank two documents when one was recorded first but was improperly indexed. See Misindexed Documents, ACMA Abstract, 2006, found at www.RogerBernhardt.com . Or when a refinancing lender had paid off the previous mortgage without taking an assignment of it and then discovered another party who also had a lien on the same property which s/he now claims is elevated over him. See "Statutory Equitable Subrogation", ACMA Abstract 2007 found at www.RogerBernhardt.com. Only the creators of Article Nine are so in love with strict priority as to be willing to say that first comes first, no matter what. (See "Simultaneous Priority", ACMA Abstract 2009, found at www.RogerBernhardt.com)

\section{What To Do if Your Client Could be a Loser}

Junior lenders in Massachusetts and Alabama should now know that their insurance protection against casualty losses is weak. Junior lenders in New Jersey, Maryland and New York can perhaps conclude the opposite, but the New Jersey and New York decisions are from lower 
courts, and thus less comforting. And in the other forty five jurisdictions, attorneys for junior lenders cannot give firm advice at all, but that is exactly what those parties need.

It is unlikely for an ordinary junior lender to think that it can enter into any kind of intercreditor agreement with the senior lender reversing their priorities as to insurance proceeds (which would make life as uncertain for the senior as it is now for the junior), or purporting to waive subrogation rights as is often done in leases, common interest developments and construction contracts, since the interests of those parties in each other is so different from that of two lenders. (It seems equally useless to propose to a junior lender that it independently seek to purchase some sort of third party gap insurance policy to cover it against the risk that the owner's carrier may honor its loss payee obligations to this lender but at the same time use its subrogation rights to defeat that lender's claim to recover the unpaid balance of the loan from what is left of the security.)

A junior lender who is averse to incurring this kind risk needs to negotiate with its real rival - the carrier - to get it to agree that its subrogation and assignment rights will be restricted so as to not trump the junior's collection rights. This probably will come about through the junior's demand upon its borrower that improved insurance coverage from the carrier will be a condition for the borrower obtaining the loan. The junior's requirement should be that not only must the borrower keep the property insured, and name the junior as an additional loss payee, and insure the junior even against losses caused by the borrower itself, but also obtain the agreement of the carrier that its subrogation and assignment rights - derived from any or all lenders - will not the impair collection rights of this particular lender.

Asking the carrier to provide such protection is probably not that hard. Carriers are not like senior lenders who need to maintain their priority over all others at all costs. They are in the business of undertaking (for compensation) to pay for losses arising from risks that others want to avoid. In that kind of environment, this new last condition is unlikely to constitute much of a deal breaker. 